ISSN 1392-3196 / e-ISSN 2335-8947

Zemdirbyste-Agriculture, vol. 101, No. 2 (2014), p. 125-132

DOI 10.13080/z-a.2014.101.016

\title{
Total, cold and hot water extractable organic carbon in soil profile: impact of land-use change
}

\author{
Zenon HAMKALO ${ }^{1}$, Tymur BEDERNICHEK ${ }^{2}$ \\ ${ }^{1}$ Ivan Franko National University of Lviv \\ 41 Doroshenko, 79000 Lviv, Ukraine \\ E-mail: zenon.hamkalo@gmail.com \\ ${ }^{2}$ M. M. Gryshko National Botanic Garden \\ 1 Timiryazevska, 01014 Kyiv, Ukraine \\ E-mail: bedernichek@gmail.com
}

\begin{abstract}
The content of labile, especially water extractable organic carbon (WEOC) is a sensible indicator of soil organic matter quality. The main objectives of this study were: i) to investigate the profile changes of cold and hot water extractable organic carbon in forest and arable soils; ii) to evaluate the correlation between these labile fractions of soil organic matter and total organic carbon content. The experiments were carried out on a Gleyic Albeluvisol $(A B g)$ in the upper part of Dniester basin, Western Ukraine. The soil samples were taken from 50-cm depth soil profile with $5-\mathrm{cm}$ step. Total organic carbon (TOC), cold water extractable organic carbon (CWEOC) and hot water extractable organic carbon (HWEOC) contents in soil were determined as well as $\mathrm{pH}\left(\mathrm{H}_{2} \mathrm{O}\right)$ and electrical conductivity of soil:water suspensions. The results of this study showed that in 0-50 cm layer of arable soil TOC content decreased by $32 \%$, CWEOC - by $23 \%$ and HWEOC - by $74 \%$ compared to forest soil that confirmed a high informative role of HWEOC fraction. The profile changes of WEOC percentage were analysed. They also show that HWEOC is much more informative indicator of soil organic matter quality than CWEOC. The most prominent changes of soil chemical properties, TOC, CWEOC and HWEOC contents in response to deforestation were observed in the top $5-\mathrm{cm}$ soil layer. We suggested this thin soil layer to be defined as soil stress-sensitive zone.
\end{abstract}

Key words: dissolved organic carbon, labile fraction, soil organic matter, total organic carbon, water-soluble organic matter.

\section{Introduction}

Soil carbon reservoir is one of the largest on the planet and contains up to $2500 \mathrm{Pg}$ (petagram, $1 \mathrm{Pg}=10^{15}$ g) $\mathrm{C}$ in upper $1 \mathrm{~m}$ layer (Batjes, 1996). It is three times larger than atmospheric carbon reservoir (Oelkers, Cole, 2008) and contains almost 4.5 times the amount of carbon in biomass (Lal, 2008). Thus the quality and quantity of soil organic matter (SOM) play the key role in global carbon balance. The most labile fractions of SOM are water-soluble organic substances (Bu et al., 2011). Due to high biodegradation rates they are an important source of carbon dioxide production and directly affect soil $\mathrm{CO}_{2}$ efflux (Gregorich et al., 2003; Kim et al., 2012).

Water extractable organic carbon (WEOC) is an important but not homogenous pool. Solubility of different organic compounds depends on the temperature of solvent. Therefore two functional pools of WEOC are usually studied: cold water extractable organic carbon (CWEOC) and hot water extractible organic carbon (HWEOC) (Ghani et al., 2003). The first one quantitatively is very close to dissolved organic carbon measured directly in soil using different lysimeters and suction cups (Rees, Parker, 2005; Ostrowska et al., 2010).
The second one consists of more stable components that form the close reserve of nutrients and energy for plants and microorganisms (Bu et al., 2011). Landgraf et al. (2006) conducted a detailed study on cold and hot water extractable organic matter as indicators of litter decomposition in forest soils. They considered HWEOC to be a heterogeneous pool, because hot $\left(\geq 70^{\circ} \mathrm{C}\right)$ water kills vegetative cells of microorganisms and extracts many components from microbial biomass, as well as many nonmicrobial organic substances. Therefore, HWEOC has much higher biodegradability rates than CWEOC (Gregorich et al., 2003). In the majority of WEOC studies only the uppermost soil layer was analyzed (Shpakivska, 2008; Ahn et al., 2009; Slepetienè et al., 2010; Ruqin et al., 2013). In fewer cases the profile changes of WEOC were investigated (Boyer, Groffman, 1996; Menyailo, 2008; Nakanishi et al., 2012).

The objectives of this study were: i) to investigate the profile changes of cold and hot water extractable organic carbon in forest and arable soils; ii) to evaluate the correlation between CWEOC, HWEOC and total organic carbon (TOC) in these soils. 


\section{Materials and methods}

Study area. The experiments were carried out on two plots $(100 \times 100 \mathrm{~m})$ in the upper part of Dniester basin, Western Ukraine $\left(49^{\circ} 32^{\prime} \mathrm{N}, 23^{\circ} 20^{\prime} \mathrm{E}\right)$. The field experimental plots were established in 2006. The first one was set up in a pristine old-growth hornbeam-oak forest. There were English oak (Quercus robur L.) $35 \%$, sycamore maple (Acer pseudoplatanus L.) - 1\% in tree stratum on the first floor and European hornbeam (Carpinus betulus L.) - 25\%, small-leaved lime (Tilia cordata Mill.) - 3\%, field maple (Acer campestre L.) $1 \%$, mountain-ash (Sorbus aucuparia L.) - 1\% in the second one. The shrub layer was represented by common hazel (Corylus avellana L.) - 7\% and common dogwood (Swida sanquinea L.) - 5\%; the herb layer - by more than 50 species among which yellow archangel (Galeobdolon luteum Huds.) - 15\%, wood sorrel (Oxalis acetosella L.) - 10\% and European woodland sedge (Carex sylvatica Huds.) $-5 \%$ were the most common. The second plot was set up in an adjacent tillable land, where the forest was clear cut about 70 years ago. The four-field crop rotation was applied: potatoes, barley + clover, clover, winter wheat. The soil (Gleyic Albeluvisol, $A B g$ ) was fertilized with cattle manure ( $40 \mathrm{t} \mathrm{ha}^{-1}$ once in four years) and mineral fertilizers $\left(\mathrm{N}_{45} \mathrm{P}_{45} \mathrm{~K}_{50}\right)$. For the last 30 years mean annual total precipitation was $697 \mathrm{~mm}$; the annual average temperature was $7.8^{\circ} \mathrm{C}$, and the sum of active temperatures - about $2400-2600^{\circ} \mathrm{C}$.

Soil sampling and analysis. Five soil pits were made on each experimental plot. For this study the soil samples were taken from $50-\mathrm{cm}$ depth soil profile, with a 5-cm step. Soil sampling was done in October 2008. The samples were taken from three sides of each soil pit and with a special bore from five points located less than $5 \mathrm{~m}$ from the pit. Fresh soil samples were passed through $3 \mathrm{~mm}$ sieve and composite samples for each 5-cm layer were taken. For all the analyses, described in this study, the soil samples were air-dried. The chemical composition was provided in dry matter. Total organic carbon (TOC) content was determined by wet combustion method (ISO 14235: 1998, Soil quality - Determination of organic carbon by sulfochromic oxidation). The absorbance of the obtained solutions was measured spectrophotometrically on a double beam UV-visible spectrophotometer SPEKOL 2000 ("Analytik Jena", UK). Content of water extractable organic carbon (WEOC) was determined according to the method of Haynes and Francis (1993) modified by Ghani et al. (2003) that consists of two-step water extraction. A $3 \mathrm{~g}$ sample of air dried soil was put into $50 \mathrm{ml}$ polypropylene centrifuge tube and $30 \mathrm{ml}$ of distilled water were added. The tube was put on endover-end shaker at $30 \mathrm{rpm}$ for $30 \mathrm{~min}$ at $20^{\circ} \mathrm{C}$. After extraction, the suspension was centrifuged at $3500 \mathrm{rpm}$ for $20 \mathrm{~min}$ and the supernatant solution was filtered through $0.45 \mu \mathrm{m}$ membrane filters. A $5 \mathrm{ml}$ portion of the obtained solution was put into a glass tube and evaporated to dryness at $60^{\circ} \mathrm{C}$. The fraction obtained is cold water extractable organic carbon (CWEOC). A $20 \mathrm{ml}$ portion of distilled water was added to the same centrifuge tube with sediments. The used membrane filter was washed with $10 \mathrm{ml}$ of distilled water, which was collected into the same tube. It was capped, shaken vigorously for $10 \mathrm{~s}$ and put into the thermostat at $80^{\circ} \mathrm{C}$ for $16 \mathrm{~h}$. After the extraction, the tube was shaken for $10 \mathrm{~s}$ once again. The suspension was centrifuged, filtered and the solution was evaporated like in previous step. Organic carbon content was determined by wet combustion method as described before. In each experiment, five replicates were taken for each soil sample. Electrical conductivity and $\mathrm{pH}$ (potentiometric) were measured in 1:2.5 soil:water suspensions on a conductivity meter "S47 SevenMulti" ("Mettler-Toledo", USA). Soil particle size distribution was measured with sedimentation technique of Kaczynski (1965).

Statistical analysis. Statistical analysis of experimental data was made according to the recommendations of Glantz (1997). For comparisons of multiple groups the Conover post hoc test (Conover, 1999) was used. The difference was considered significant when $P<0.05$. Linear and exponential regressions analysis was used to model the profile changes of TOC, CWEOC and hot water extractable organic carbon (HWEOC) contents in soil with depth. The linear regression was used to model the relationship between TOC, CWEOC and HWEOC contents in soil. Pearson correlation coefficient was used as a measure of the strength of linear dependence between studied parameters (Rodgers, Nicewander, 1988). Statistical analyses were performed using the MS Excel 2010 with add-in AtteStat 12.5 .

\section{Results and discussion}

All of the measured basic chemical properties of studied forest soil displayed a dependency on soil depth (Table 1). The average TOC content in the forest soil was $15.6 \mathrm{mg} \mathrm{g}^{-1} \mathrm{C}$ in the studied $0-50 \mathrm{~cm}$ layer. A significant decrease of TOC content with depth was observed from 59.78 in top 5-cm soil layer to $2.53 \mathrm{mg} \mathrm{g}^{-1} \mathrm{C}$ at the depth $45-50 \mathrm{~cm}$. This dependence can be approximated by the exponential equation $\mathrm{y}=43.914 \mathrm{e}^{-0.06 \mathrm{x}}(P<0.01 ; \mathrm{n}=10)$. Here and elsewhere we used medians ( 5 soil pits) to perform exponential or linear regression analysis. The decrease of soil acidity with depth was also observed. The lowest $\mathrm{pH}\left(\mathrm{H}_{2} \mathrm{O}\right)$ values (4.24-4.33) were determined in the top $0-5 \mathrm{~cm}$ soil layer. In the lower portion of the profile, at the depth $40-50 \mathrm{~cm}$ they reach almost 5.0. The highest values of electrical conductivity (EC) were also confined to the uppermost soil layers, where they reached $75 \mu \mathrm{Sm} \mathrm{cm}^{-1}$. In particular, in the top horizons the electrical conductivity values were approximately twice as high as those in the deeper layers $\left(34 \mu \mathrm{Sm} \mathrm{cm}^{-1}\right)$. TOC content and EC values slightly increased in soil layer 40$45 \mathrm{~cm}$ where the zones of illuviation were formed.

Over 70 years of agricultural exploitation of the deforested soil, its properties dramatically changed (Table 2). Well stratified organoprofile of forest soil was simplified. The average TOC content in the forest soil of $0-50 \mathrm{~cm}$ layer was $11.9 \mathrm{mg} \mathrm{g}^{-1} \mathrm{C}$. The dependence of TOC content and soil depth can be approximated not by the exponential equation as in previous variant, but by a simple linear function $\mathrm{y}=19.527-0.305 \mathrm{x}(r=-0.97$, $P<0.001 ; \mathrm{n}=10)$. Very similar equation $\mathrm{y}=18.047-$ $0.289 x(r=-0.9743, P<0.001 ; \mathrm{n}=10)$ can be used to model the profile changes of EC in this soil. The absolute values of TOC and EC decreased twice in comparison to forest soils. Regarding $\mathrm{pH}$ of studied arable soil, it is more than 10 times greater than in forest soil: 5.67 versus 4.31 in top 5-cm layer. It slightly increased with depth up to 5.82 in the layer $45-50 \mathrm{~cm}$. 
Table 1. Basic chemical properties of forest soil

\begin{tabular}{|c|c|c|c|c|c|c|c|c|c|}
\hline \multirow{2}{*}{$\begin{array}{l}\text { Depth } \\
\mathrm{cm}\end{array}$} & \multicolumn{3}{|c|}{$\begin{array}{l}\text { Total organic carbon (TOC) } \\
\qquad \mathrm{mg} \mathrm{g}^{-1} \mathrm{C}\end{array}$} & \multicolumn{3}{|c|}{$\mathrm{pH}\left(\mathrm{H}_{2} \mathrm{O}\right)$} & \multicolumn{3}{|c|}{$\begin{array}{l}\text { Electrical conductivity (EC) } \\
\mu \mathrm{Sm} \mathrm{cm}^{-1}\end{array}$} \\
\hline & med & $\max$ & $\min$ & med & $\max$ & $\min$ & med & $\max$ & $\min$ \\
\hline $0-5$ & 59.78 & 69.50 & 51.00 & 4.31 & 4.33 & 4.24 & 75.0 & 63.0 & 83.0 \\
\hline $5-10$ & 26.70 & 29.61 & 21.93 & 4.35 & 4.39 & 4.30 & 40.0 & 38.0 & 46.0 \\
\hline $10-15$ & 17.69 & 19.24 & 14.82 & 4.40 & 4.47 & 4.39 & 42.0 & 40.0 & 44.0 \\
\hline $15-20$ & 12.86 & 14.62 & 10.54 & 4.47 & 4.55 & 4.45 & 27.0 & 24.0 & 31.0 \\
\hline $20-25$ & 11.87 & 13.42 & 10.02 & 4.59 & 4.62 & 4.54 & 37.0 & 34.0 & 41.0 \\
\hline $25-30$ & 10.22 & 12.29 & 8.92 & 4.61 & 4.62 & 4.55 & 34.0 & 32.0 & 39.0 \\
\hline $30-35$ & 7.14 & 8.16 & 6.51 & 4.67 & 4.71 & 4.58 & 35.0 & 34.0 & 40.0 \\
\hline $35-40$ & 3.08 & 4.03 & 2.41 & 4.80 & 4.82 & 4.74 & 27.0 & 23.0 & 29.0 \\
\hline $40-45$ & 4.18 & 5.16 & 3.15 & 4.95 & 5.04 & 4.93 & 45.0 & 41.0 & 48.0 \\
\hline $45-50$ & 2.53 & 3.03 & 1.90 & 4.92 & 4.97 & 4.86 & 34.0 & 32.0 & 39.0 \\
\hline
\end{tabular}

med - median, $\max -$ maximum, $\min -$ minimum; $\mathrm{n}=5$ for each soil layer

Table 2. Basic chemical properties of arable soil

\begin{tabular}{|c|c|c|c|c|c|c|c|c|c|}
\hline \multirow{2}{*}{$\begin{array}{l}\text { Depth } \\
\mathrm{cm}\end{array}$} & \multicolumn{3}{|c|}{$\begin{array}{l}\text { Total organic carbon (TOC) } \\
\qquad \mathrm{mg} \mathrm{g}^{-1} \mathrm{C}\end{array}$} & \multicolumn{3}{|c|}{$\mathrm{pH}\left(\mathrm{H}_{2} \mathrm{O}\right)$} & \multicolumn{3}{|c|}{$\begin{array}{l}\text { Electrical conductivity (EC) } \\
\mu \mathrm{Sm} \mathrm{cm}^{-1}\end{array}$} \\
\hline & med & $\max$ & $\min$ & med & $\max$ & $\min$ & med & $\max$ & $\min$ \\
\hline $0-5$ & 19.48 & 20.55 & 18.30 & 5.67 & 5.71 & 5.60 & 34.0 & 32.5 & 38.0 \\
\hline $5-10$ & 16.45 & 18.04 & 16.10 & 5.55 & 5.60 & 5.48 & 30.0 & 26.0 & 32.0 \\
\hline $10-15$ & 17.29 & 18.58 & 15.15 & 5.60 & 5.61 & 5.54 & 29.0 & 26.0 & 32.0 \\
\hline $15-20$ & 14.85 & 15.50 & 13.05 & 5.62 & 5.71 & 5.53 & 27.0 & 23.0 & 29.0 \\
\hline $20-25$ & 10.85 & 11.51 & 9.82 & 5.64 & 5.73 & 5.61 & 25.0 & 21.0 & 26.0 \\
\hline $25-30$ & 10.05 & 10.23 & 8.55 & 5.70 & 5.78 & 5.69 & 26.0 & 25.0 & 29.0 \\
\hline $30-35$ & 9.05 & 9.55 & 8.25 & 5.73 & 5.79 & 5.70 & 30.0 & 27.0 & 32.5 \\
\hline $35-40$ & 7.80 & 8.55 & 7.14 & 5.81 & 5.85 & 5.77 & 31.0 & 30.0 & 35.0 \\
\hline $40-45$ & 7.18 & 7.60 & 6.23 & 5.78 & 5.84 & 5.71 & 28.0 & 24.0 & 31.5 \\
\hline $45-50$ & 6.03 & 6.90 & 5.70 & 5.82 & 5.91 & 5.80 & 27.5 & 24.0 & 32.0 \\
\hline
\end{tabular}

med - median, $\max -$ maximum, $\min -$ minimum; $\mathrm{n}=5$ for each soil layer

All the basic chemical properties are strongly related to particle size distribution. It affects the reactivity of solids in soil which participate in various chemical reactions. Soil texture may influence the acidity values in soil profile and the rates of accumulation and mineralization of soil organic matter (SOM). Clay content in soil may provide important information about the pattern of illuviation. Comparison of data in Tables 1,2 and 3 showed that $\mathrm{pH}\left(\mathrm{H}_{2} \mathrm{O}\right)$, TOC and clay content often change in studied soil profiles simultaneously.

Table 3. Particle size distribution of forest and arable soils

\begin{tabular}{|c|c|c|c|c|c|c|}
\hline \multirow{2}{*}{$\begin{array}{l}\text { Depth } \\
\mathrm{cm}\end{array}$} & \multicolumn{3}{|c|}{ Forest soil } & \multicolumn{3}{|c|}{ Arable soil } \\
\hline & $\begin{array}{c}\text { sand \% } \\
(1.0-0.01 \mathrm{~mm})\end{array}$ & $\begin{array}{c}\text { silt \% } \\
(0.01-0.001 \mathrm{~mm})\end{array}$ & $\begin{array}{c}\text { clay } \% \\
(<0.001 \mathrm{~mm})\end{array}$ & $\begin{array}{c}\text { sand \% } \\
(1.0-0.01 \mathrm{~mm})\end{array}$ & $\begin{array}{c}\text { silt \% } \\
(0.01-0.001 \mathrm{~mm})\end{array}$ & $\begin{array}{c}\text { clay } \% \\
(<0.001 \mathrm{~mm})\end{array}$ \\
\hline $0-5$ & 23.0 & 71.4 & 5.6 & 39.2 & 52.1 & 8.7 \\
\hline $5-10$ & 26.8 & 63.5 & 9.7 & 36.9 & 56.0 & 7.1 \\
\hline $10-15$ & 27.9 & 64.3 & 7.8 & 37.9 & 55.2 & 6.9 \\
\hline $15-20$ & 29.4 & 62.5 & 8.1 & 39.1 & 54.1 & 6.8 \\
\hline $20-25$ & 30.9 & 53.1 & 16.0 & 50.4 & 42.4 & 7.3 \\
\hline $25-30$ & 29.1 & 61.9 & 9.0 & 58.4 & 25.0 & 16.6 \\
\hline $30-35$ & 30.0 & 58.9 & 11.0 & 51.3 & 30.9 & 17.8 \\
\hline $35-40$ & 30.8 & 58.0 & 11.2 & 41.7 & 44.0 & 14.3 \\
\hline $40-45$ & 36.0 & 54.2 & 9.8 & 53.4 & 26.7 & 19.9 \\
\hline $45-50$ & 29.4 & 61.5 & 9.1 & 64.9 & 15.9 & 19.2 \\
\hline
\end{tabular}


Small sizes of soil particles cause their high sorptive potential. Therefore, the zones of high clay content should be rich in water extractable organic matter. In forest soil the average CWEOC content in 0-50 cm layer was $0.36 \mathrm{mg} \mathrm{g}^{-1} \mathrm{C}$. The highest amount of cold water extractable organic matter (Fig. 1) was located in the uppermost layer $0-5 \mathrm{~cm}\left(0.7-0.89 \mathrm{mg} \mathrm{g}^{-1} \mathrm{C}\right)$. CWEOC content gradually decreased with depth to $0.03-0.08 \mathrm{mg} \mathrm{g}^{-1} \mathrm{C}$ in the layer $45-50 \mathrm{~cm}$. This dependence can be approximated by the exponential equation $\mathrm{y}=1.0856 \mathrm{e}^{-0.057 \mathrm{x}}(P<0.001 ; \mathrm{n}=10)$. In contrast, profile changes of CWEOC in arable soil had different pattern. In comparison to forest soil, it can be seen that deforestation and agricultural exploitation caused significant decrease of CWEOC in top soil layer to $15 \mathrm{~cm}$ depth. The average content of CWEOC in $0-50 \mathrm{~cm}$ soil layer decreased to $0.29 \mathrm{mg} \mathrm{g}^{-1} \mathrm{C}$. Another important observation is that a zone of CWEOC accumulation was formed at the depth of $25-40 \mathrm{~cm}$. In this layer clay content is the highest (16.6-19.9\%) in studied $50-\mathrm{cm}$ soil profile.
A possible explanation for this might be that ploughing depth was about $25 \mathrm{~cm}$. Therefore, after the tillage the most labile fraction of SOM might have been eluted down the soil profile and sorbed on the surface of clay particles (Corvasce et al., 2006). These changes are associated with significant decrease of TOC content in arable soil compared to forest soil. In our previous studies we investigated the impacts of deforestation on readily oxidizable organic carbon content in forest and arable soils (Partyka, Hamkalo, 2010). Here we found that the profile changes of CWEOC and the content of organic carbon hydrolyzed with $10 \% \mathrm{H}_{2} \mathrm{SO}_{4}$ have much in common content of both these fractions decrease dramatically in uppermost layer of deforested soil. These findings further support the idea that even principally different SOM extraction techniques may evaluate chemically similar fractions of SOM that form its active pool (von Lützow et al., 2007).

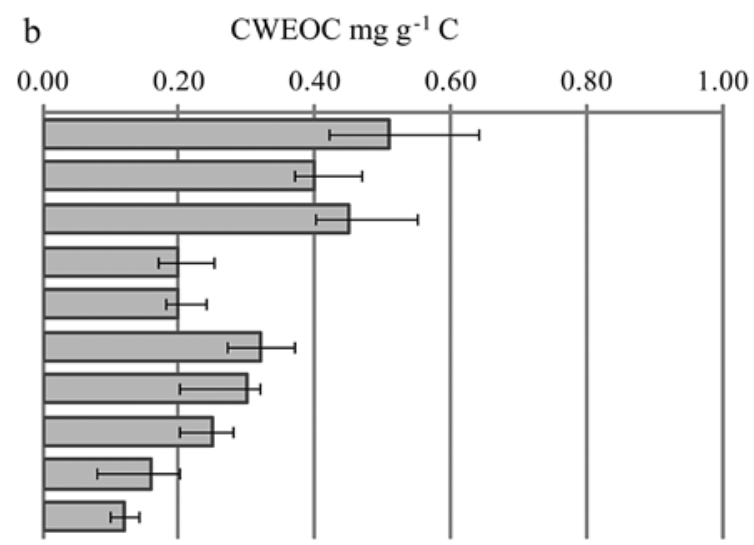

Note. Bars represent median, maximum and minimum; $\mathrm{n}=5$ for each soil layer.

Figure 1. Cold $\left(20^{\circ} \mathrm{C}\right)$ water extractable organic carbon (CWEOC) in forest (a) and arable (b) soils

Figure 2 illustrates the profile changes of HWEOC. This data evidently displays that highest amounts (8.35-9.43 $\mathrm{mg} \mathrm{g}^{-1} \mathrm{C}$ ) of this fraction were located in the top 5-cm layer of forest soil. It was 2.1 times higher than at the 5-10 cm depth. HWEOC content gradually decreased with depth to $0.95-1.34 \mathrm{mg} \mathrm{g}^{-1} \mathrm{C}$ in $15-20 \mathrm{~cm}$ soil layer and to $0.29-0.41 \mathrm{mg} \mathrm{g}^{-1} \mathrm{C}$ at the

a

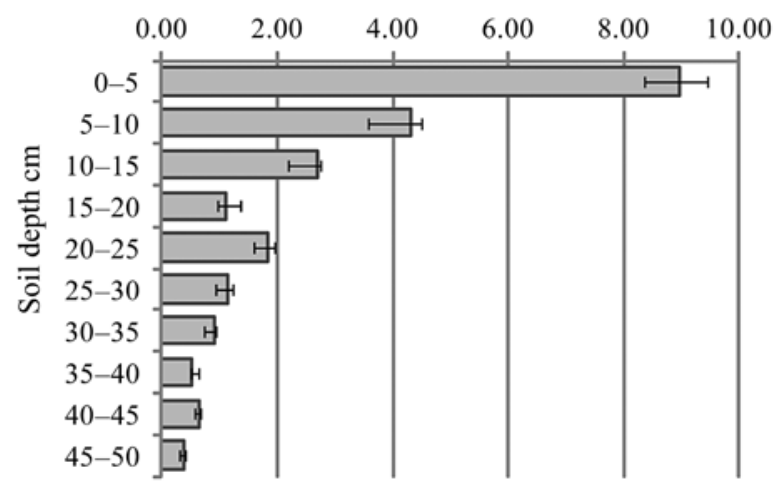

45-50 $\mathrm{cm}$ depth. The dependence of HWEOC content and soil depth can be approximated by the exponential equation $\mathrm{y}=6.5482 \mathrm{e}^{-0.062 \mathrm{x}}(P=0.006 ; \mathrm{n}=10)$. Conversely, profile changes of HWEOC in studied arable soil had different pattern. It was only $2.01-2.55 \mathrm{mg} \mathrm{g}^{-1} \mathrm{C}$ in top 5 -cm soil layer -3.8 times lower than in forest soil. The dependence between HWEOC content and soil depth can

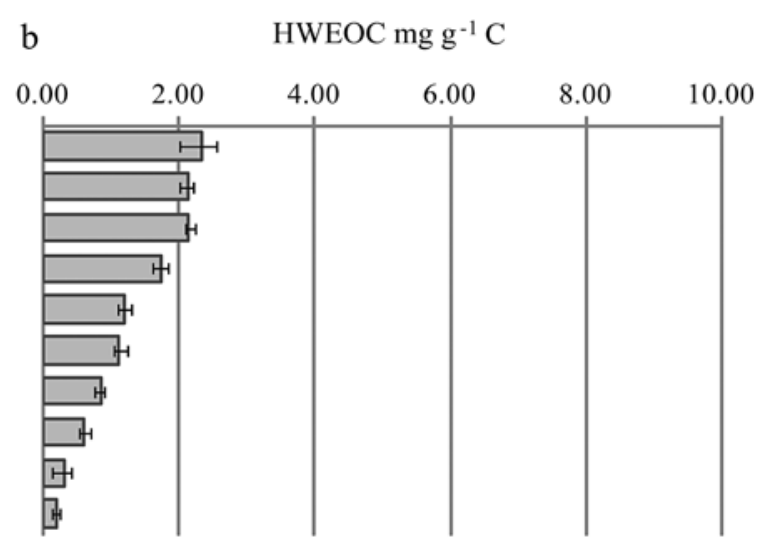

Note. Bars represent median, maximum and minimum; $\mathrm{n}=5$ for each soil layer.

Figure 2. Hot $\left(80^{\circ} \mathrm{C}\right)$ water extractable organic carbon (HWEOC) in forest (a) and arable (b) soils 

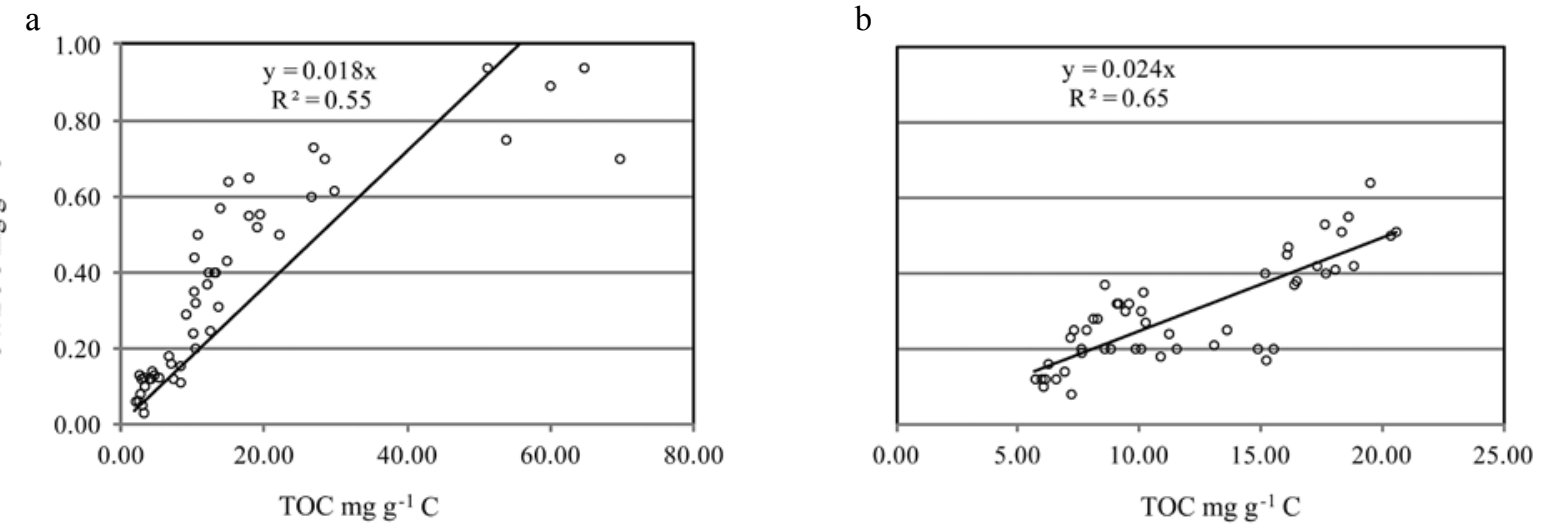

Note. $R^{2}$ - coefficient of determination; both regression lines are statistically significant at the $P<0.01$ level; $\mathrm{n}=50$.

Figure 3. The dependence of cold $\left(20^{\circ} \mathrm{C}\right)$ water extractable $(\mathrm{CWEOC})$ and total organic carbon (TOC) contents in forest (a) and arable (b) soils

be approximated by a simple linear function $\mathrm{y}=2.5627$ $-0.0517 \mathrm{x}(r=-0.99, P<0.001 ; \mathrm{n}=10)$. The avarage content of this fraction was 2.24 and $1.27 \mathrm{mg} \mathrm{g}^{-1} \mathrm{C}$ in $0-50$ layer of forest and arable soil, respectively. The findings of the current study are consistent with those of Ruqin et al. (2013) who found that HWEOC content in $0-30 \mathrm{~cm}$ layer was $58.8 \%$ lower in cultivated than in uncultivated soils.

The most prominent changes of basic chemical properties (Tables 1-2), CWEOC and WEOC contents in studied forest and arable soils were observed in the top 5-cm soil layer. We propose it to be defined as a "soil stress-sensitive zone". A strong relationship between WEOC and TOC has been reported in the literature (Zsolnay, Görlitz, 1994; Corvasce et al., 2006). As can be seen from Figure 3, the contents of CWEOC and TOC are likewise related in studied $0-50 \mathrm{~cm}$ soil profile. It arouses interest that a stronger correlation between these

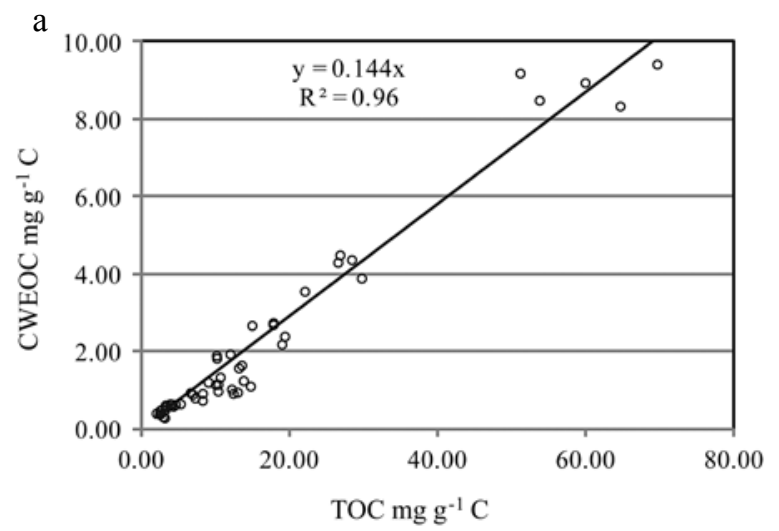

parameters was found in arable (0.81) compared to that in forest soil (0.74).

Weigel et al. (2011) reported a strong correlation between HWEOC and TOC. They considered it to confirm that the HWEOC fraction was more related to labile carbon and thus reflected carbon changes as affected by land management. In our studies (Fig. 4) we also found a very strong correlation between these fractions: 0.98 in forest and 0.91 in arable soils. This may be explained by high content of non-humified organic material in forest soil such as lignin, lignocaeloulose and other carbohydrates that may be partly extracted with hot water (Wang, Wang, 2007). Another possible explanation may be the higher content of microbial, especially fungal, biomass in forest soils that is also extracted by hot water (Boyer, Groffman, 1996; Bu et al., 2011). The discovered quantitative changes of CWEOC and HWEOC fractions as well as their correlations with total

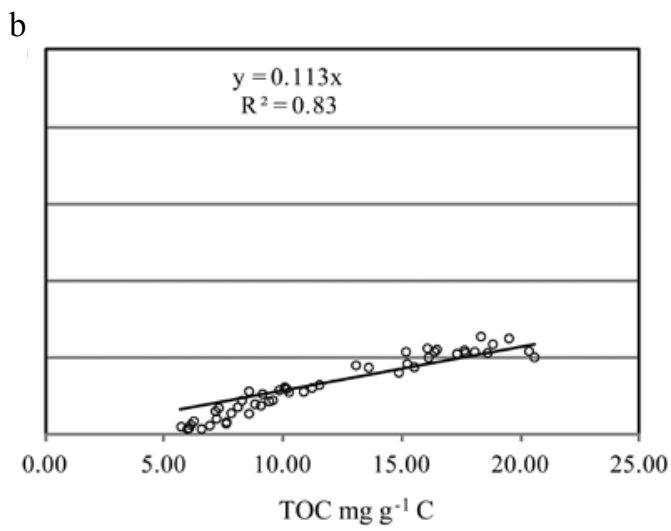

Note. $R^{2}$ - coefficient of determination; both regression lines are statistically significant at the $P<0.01$ level; $\mathrm{n}=50$.

Figure 4. The dependence of hot $\left(80^{\circ} \mathrm{C}\right)$ water extractable (HWEOC) and total organic carbon (TOC) contents in forest (a) and arable (b) soils

organic carbon content in studied soils proved the deep chemical transformation of SOM during deforestation and agricultural exploitation.

The results, as shown in Table 3, indicate that the percentage of water extractable organic carbon (CWEOC and HWEOC) in TOC was significantly lower in arable than in forest soil (Table 3). In $0-50 \mathrm{~cm}$ soil layer the average percentage of CWEOC was $2.72 \%$ in forest and $2.48 \%$ in arable soil. For HWEOC fraction it was $14.08 \%$ and $9.65 \%$ in forest and arable soil, respectively. It is therefore likely that HWEOC is a much more informative indicator of soil organic matter quality than CWEOC. 
Table 3. Percentage of water extractable organic carbon (WEOC, CWEOC, HWEOC) in total organic carbon (TOC)

\begin{tabular}{ccccccc}
\hline \multirow{2}{*}{$\begin{array}{c}\text { Depth } \\
\mathrm{cm}\end{array}$} & \multicolumn{2}{c}{$\begin{array}{c}\text { Percentage (\%) of } \\
\text { CWEOC in TOC }\end{array}$} & \multicolumn{2}{c}{$\begin{array}{c}\text { Percentage (\%) of } \\
\text { HWEOC in TOC }\end{array}$} & \multicolumn{2}{c}{$\begin{array}{c}\text { Percentage (\%) of } \\
\text { WEOC in TOC }\end{array}$} \\
\cline { 2 - 7 } & forest soil & arable soil & forest soil & arable soil & forest soil & arable soil \\
\hline $0-5$ & 1.49 & 2.62 & 14.98 & 12.06 & 16.47 & 14.68 \\
$5-10$ & 2.30 & 2.43 & 16.13 & 13.07 & 18.44 & 15.50 \\
$10-15$ & 3.13 & 2.60 & 15.13 & 12.43 & 18.26 & 15.04 \\
$15-20$ & 3.35 & 1.35 & 8.61 & 11.78 & 11.96 & 13.13 \\
$20-25$ & 3.11 & 1.84 & 15.42 & 11.06 & 18.53 & 12.90 \\
$25-30$ & 2.41 & 3.18 & 11.25 & 11.14 & 13.66 & 14.33 \\
$30-35$ & 2.15 & 3.31 & 12.50 & 9.50 & 14.65 & 12.82 \\
$35-40$ & 3.90 & 3.21 & 16.48 & 7.69 & 20.38 & 10.90 \\
$40-45$ & 2.94 & 2.23 & 15.09 & 4.46 & 18.03 & 6.69 \\
$45-50$ & 2.37 & 1.99 & 15.20 & 3.32 & 17.57 & 5.31 \\
\hline
\end{tabular}

$\mathrm{n}=5$ for each soil layer

Mineralization of soil organic matter and especially its labile fractions causes the input of particles in ionic form such as $\mathrm{H}^{+}, \mathrm{NO}_{3}^{-}, \mathrm{NH}_{4}^{+}, \mathrm{HCO}_{3}^{-}, \mathrm{HPO}_{4}^{2-}$, $\mathrm{H}_{2} \mathrm{PO}_{4}^{-}$, etc. in soil (Bedernichek et al., 2009). Taking into consideration significant change of electrical conductivity in arable compared to forest soil (Tables 1-2), it could be hypothesized that not only labile organic matter content, but the whole mineralization potential of soil has decreased. The most labile fraction of SOM - water extractable organic matter - consists of the substances with low activation energy barrier, so a depletion of WEOC pool might change the temperature sensitivity of soil (Wagai et al., 2013). Therefore the investigation of carbon dioxide emission rates from studied forest and arable soils is an important issue for future research.

\section{Conclusions}

This study was undertaken to evaluate the impact of deforestation and agriculture exploitation of Gleyic Albeluvisol (ABg) on distribution of total, cold and hot water extractable organic carbon in soil profile. The following conclusions can be drawn from the present research:

1. In response to forest conversion, the most prominent changes of soil chemical properties, total organic carbon (TOC), cold water extractable organic carbon (CWEOC) and hot water extractable organic carbon (HWEOC) contents were observed in the top $5-\mathrm{cm}$ soil layer. We proposed it to be defined as soil stress-sensitive zone.

2. Over 70 years of agricultural exploitation of the deforested soil caused dramatic changes in its properties. Well stratified organoprofile of forest soil was simplified. The relationship between TOC content and soil depth in arable soil can be approximated not by the exponential equation as in forest, but by a simple linear function $(r=-0.97, P<0.001 ; \mathrm{n}=10)$.

3. In studied $0-50 \mathrm{~cm}$ layer of arable soil TOC content decreased by $32 \%$, CWEOC by $23 \%$ and
HWEOC by $74 \%$ compared to forest soil $(n=50)$. That confirmed a high informative role of HWEOC fraction.

4. The contents of CWEOC and TOC in studied $0-50 \mathrm{~cm}$ soil profile were closely related. There was a stronger correlation between these parameters in arable soil $(r=0.81, P<0.01)$ than in forest soil $(r=0.74$, $P<0.01)$. Additionally, very strong correlations between HWEOC and TOC contents were observed: 0.91 $(P<0.01)$ in arable and $0.98(P<0.01)$ in forest soils.

5. Electrical conductivity of soil:water suspension significantly decreased in arable soil in comparison to forest soil: 34 versus $75 \mu \mathrm{Sm} \mathrm{cm}^{-1}$. This fact might indicate the decrease of the whole mineralization potential of soil under the influence of deforestation and agriculture exploitation.

\section{Acknowledgements}

We are highly grateful to LG Electronics for financial support (award to Tymur Bedernichek), which made it possible to carry out this study. Also we would like to thank the two anonymous reviewers whose comments helped to improve and clarify this manuscript.

Received 14062013

Accepted 12032014 


\section{References}

Ahn M.-Y., Zimmerman A. R., Comerford N. B., Sickman J. O., Grunwald S. 2009. Carbon mineralization and labile organic carbon pools in the sandy soils of a North Florida Watershed. Ecosystems, 12: 672-685 http://dx.doi.org/10.1007/s10021-009-9250-8

Batjes N. H. 1996. Total C and N in soils of the world. European Journal of Soil Science, 47: 151-163 http://dx.doi.org/10.1111/j.1365-2389.1996.tb01386.x

Bedernichek T., Partyka T., Hamkalo Z. 2009. Electrical conductivity as quick indicator of ionic activity in forest soil. Biological Systems, 1: 85-89 (in Ukrainian)

Boyer J. N., Groffman P. M. 1996. Bioavailability of water extractable organic carbon fractions in forest and agricultural soil profiles. Soil Biology and Biochemistry, 28 (6): 783 $790 \mathrm{http} / / / \mathrm{dx}$. doi.org/10.1016/0038-0717(96)00015-6

Bu X., Ding J., Wang L., Yu X., Huang W., Ruan H. 2011. Biodegradation and chemical characteristics of hot-water extractable organic matter from soils under four different vegetation types in the Wuyi Mountains, southeastern China. European Journal of Soil Biology, 48 (2): 102-107 http://dx.doi.org/10.1016/j.ejsobi.2010.11.009

Conover W. J. 1999. Practical nonparametric statistics ( $3^{\text {rd }}$ ed.)

Corvasce M., Zsolnay A., D’Orazio V., Lopez R., Miano T. M. 2006. Characterization of water extractable organic matter in a deep soil profile. Chemosphere, 62: 1583-1590 http://dx.doi.org/10.1016/j.chemosphere.2005.07.065

Ghani A., Dexter M., Perrott K. W. 2003. Hot-water extractable carbon in soils; a sensitive measurement for determining impacts of fertilisation, grazing and cultivation. Soil Biology and Biochemistry, 35 (9): 1231-1243 http://dx.doi.org/10.1016/S0038-0717(03)00186-X

Glantz S. A. 1997. Primer of biostatistics (4 ${ }^{\text {th }}$ ed.)

Gregorich E. G., Beare M. H., Stoklas U., St-Georges P. 2003. Biodegradability of soluble organic matter in maizecropped soils. Geoderma, 113: 237-252 http://dx.doi.org/10.1016/S0016-7061(02)00363-4

Haynes R. J., Francis G. S. 1993. Changes in microbial biomass $\mathrm{C}$, soil carbohydrate composition and aggregate stability induced by growth of selected crop and forage species under field conditions. Journal of Soil Science, 44: 665675 http://dx.doi.org/10.1111/j.1365-2389.1993.tb02331.x

Kaczynski N. A. 1965. Physics of the soil

Kim Y. S., Yi M. J., Lee Y. Y., Son Y., Koike T. 2012. Characteristics of soil $\mathrm{CO}_{2}$ efflux in even-aged alder compared to Korean pine plantations in Central Korea Journal of Forest Science, 28 (4): 232-241 http://dx.doi.org/10.7747/JFS.2012.28.4.232

Lal R. 2008. Carbon sequestration. Philosophical Transactions of the Royal Society, Series B, 363: 815-830 http://dx.doi.org/10.1098/rstb.2007.2185

Landgraf D., Leinweber P., Makeschin F. 2006. Cold and hot water extractable organic matter as indicators of litter decomposition in forest soils. Journal of Plant Nutrition and Soil Science, 169: 76-82 http://dx.doi.org/10.1002/jpln.200521711

Menyailo O.V.2008. The effect of afforestation on mineralization of soil organic matter. Russian Journal of Ecology, 39 (1) 21-25 http://dx.doi.org/10.1134/S1067413608010049

Nakanishi T., Atarashi-Andoh M., Koarashi J., Saito-Kokubu Y., Hirai K. 2012. Carbon isotopes of water-extractable organic carbon in a depth profile of forest soil imply a dynamic relationship with soil carbon. European Journal of Soil Science, 63 (4): 495-500 http://dx.doi.org/10.1111/j.1365-2389.2012.01465.x
Oelkers E. H., Cole D. R. 2008. Carbon dioxide sequestration: a solution to a global problem. Elements, 4: 305-310 http://dx.doi.org/10.2113/gselements.4.5.305

Ostrowska A., Porębska G., Kanafa M. 2010. Carbon accumulation and distribution in profiles of forest soils. Polish Journal of Environmental Studies, 19 (6): 1307-1315

Partyka T., Hamkalo Z. 2010. Estimation of oxidizing ability of organic matter of forest and arable soil. ZemdirbysteAgriculture, 97 (1): 33-40

Rees R. M., Parker J. P. 2005. Filtration increases the correlation between water extractable organic carbon and soil microbial activity. Soil Biology and Biochemistry, 37 (12): 2240 2248 http://dx.doi.org/10.1016/j.soilbio.2005.03.024

Rodgers J. L., Nicewander W. A. 1988. Thirteen ways to look at the correlation coefficient. The American Statistician, 42 (1): 59-66 http://dx.doi.org/10.2307/2685263

Ruqin F., Xiaoping Z., Yan S., Xueming Y., Aizhen L. 2013. Near-infrared spectroscopic assessment of hot water extractable and oxidizable organic carbon in cultivated and uncultivated Mollisols in China. Acta Agriculturae Scandinavica, B, 63 (1): 37-45 http://dx.doi.org/10.1080/09064710.2012.711353

Shpakivska I. 2008. Water-extractable carbon in the soils of terrestrial ecosystems of Skolivski Beskydy (Ukrainian Carpathians). Visnyk of Lviv University (Biology series), 48: 89-96 (in Ukrainian)

Šlepetienė A., Šlepetys J., Liaudanskienè I. 2010. Chemical composition of differently used Terric Histosol. Zemdirbyste-Agriculture, 97 (2): 25-32

von Lützow M., Kögel-Knabner I., Ekschmitt K., Flessa H., Guggenberger G., Matzner E., Marschner B. 2007. SOM fractionation methods: relevance to functional pools and to stabilization mechanisms. Soil Biology and Biochemistry, 39 (9): 2183-2207

http://dx.doi.org/10.1016/j.soilbio.2007.03.007

Wagai R., Kishimoto-Mo A. Y., Yonemura S., Shirato Y., Hiradate S., Yagasaki Y. 2013. Linking temperature sensitivity of soil organic matter decomposition to its molecular structure, accessibility, and microbial physiology. Global Change Biology, 19 (4): 1114-1125 http://dx.doi.org/10.1111/gcb.12112

Wang Q. K., Wang S. L. 2007. Soil organic matter under different forest types in Southern China. Geoderma, 142: 349-356 http://dx.doi.org/10.1016/j.geoderma.2007.09.006

Weigel A., Eustice T, van Antwerpen R., Naidoo G., Schulz E. 2011. Soil organic carbon (SOC) changes indicated by hot water extractable carbon (HWEC). Proceedings of the South African Sugar Technologists' Association, 84: 210-222

Zsolnay A., Görlitz H. 1994. Water extractable organic matter in arable soils: effects of drought and long-term fertilization. Soil Biology and Biochemistry, 26 (9): 1257-1261 http://dx.doi.org/10.1016/0038-0717(94)90151-1 
ISSN 1392-3196 / e-ISSN 2335-8947

Zemdirbyste-Agriculture, vol. 101, No. 2 (2014), p. 125-132

DOI $10.13080 / \mathrm{z}-\mathrm{a} .2014 .101 .016$

\title{
Suminė šaltu ir karštu vandeniu ekstrahuota organinė anglis dirvožemio profilyje: žemėnaudos pakeitimo įtaka
}

\author{
Z. Hamkalo ${ }^{1}$, T. Bedernichek ${ }^{2}$ \\ ${ }^{1}$ Lvovo Ivano Franko nacionalinis universitetas, Ukraina \\ ${ }^{2}$ M. M. Gryško nacionalinis botanikos sodas, Ukraina
}

\section{Santrauka}

Labilios, ypač vandeniu ekstrahuotos organinès anglies kiekis yra informatyvus dirvožemio organinės medžiagos kokybės rodiklis. Tyrimo uždaviniai: 1) ištirti šaltu ir karštu vandeniu ekstrahuotos organinès anglies profilio pokyčius miško ir ariamoje žemėje, 2) nustatyti koreliaciją tarp dirvožemio organinès medžiagos labilių frakcijų ir suminès organinès anglies kiekio. Bandymai vykdyti Vakarų Ukrainoje, viršutinejje Dniestro baseino dalyje, glëjiškame balkšvažemyje (JIg). Dirvožemio èminiai buvo paimti iš $50 \mathrm{~cm}$ gylio profilio kas $5 \mathrm{~cm}$. Nustatyta suminès organinès anglies, šaltu ir karštu vandeniu estrahuotos organinės anglies kiekiai dirvožemyje, taip pat $\mathrm{pH}$ $\left(\mathrm{H}_{2} \mathrm{O}\right)$ ir dirvožemio vandens suspensijų elektrinis laidumas. Tyrimo rezultatai parodè, kad dirvožemio $0-50 \mathrm{~cm}$ sluoksnyje suminès organinès anglies kiekis sumažèjo $32 \%$, šaltu vandeniu ekstrahuotos organinès anglies - 23 $\%$, karštu vandeniu ekstrahuotos organinès anglies - 74 \%, palyginus su miško dirvožemiu, ir tai patvirtino didelę karštu vandeniu ekstrahuotos organinès anglies frakcijos įtaką. Išanalizuoti procentiniai vandeniu ekstrahuotos organinès anglies pokyčiai dirvožemio profilyje. Jie parodè, kad karštu vandeniu ekstrahuota organinė anglis yra žymiai informatyvesnis dirvožemio organinès medžiagos kokybės rodiklis, palyginus su tirpia šaltame vandenyje. Ryškiausi dirvožemio cheminių savybių - suminès, šaltame ir karštame vandenyje tirpios organinès anglies kiekių pokyčiai, ịvykę del miško iškirtimo, buvo nustatyti dirvožemio viršutiniame $(5 \mathrm{~cm})$ sluoksnyje. Šis plonas dirvožemio sluoksnis yra apibrěžiamas kaip stresui jautri zona.

Reikšminiai žodžiai: dirvožemio organinè medžiaga, labili frakcija, suminė organinė anglis, tirpi organinė anglis, vandenyje tirpi organinè medžiaga. 